\title{
Selective Reduction of Carbonyl Compounds with $B$-Trifluoromethane- sulfonyldiisopinocampheylborane in Ethyl Ether
}

\author{
Jin Soon Cha \\ Department of Chemistry, Keungnam Cniversit, Gvongsan 712-749. Korea. E-mail: jschaiâuack \\ Received March 11, 2009, Accepted June 4, 2009
}

Key Words: $B$-Trifluoromethanesulfonyldiisopinocampheylborane, Reduction of aldelydes and ketones. MPV-type reduction. Selective reduction. $\mathrm{Ip}_{2} \mathrm{BOSO}_{2} \mathrm{CF}_{2}$

In the previous reports. ${ }^{l-4}$ we showed that Lewis acidity of trisubstituted borane derivatives a series of new MeerweinPonndorf-Verley (MPV) type borane reagents, plays a role in part on their reactivity toward the reduction of carbonyl compounds: for example. the strong electron-withdrawing effect of fluorine substituent of $B$-trifluoroacetoxydiisopinocampheylborane ( $\mathrm{Ip}_{2} \mathrm{BO}_{2} \mathrm{CF}_{3}$ ) makes it much more reactive than Ipc_BOAc itself. This phenomenon strongly indicates the reaction proceeds by the activation of carbonyl group through coordination of Lewis acidic boron atom followed by hydride transfer from $\beta$-hydrogen source to the carbonyl acceptor wa the six-membered transition state. quite similar to the mechanism which is generally accepted in the original MPV reaction using aluminum isopropoxide.

From such mechanistic point of view, we extended to design other derivative $B$-trifluoromethanesulfony ldiisopinocampheylborane ( $\mathrm{Ipc}_{2} \mathrm{BOSO}_{2} \mathrm{CF}_{3}$ ). Evidently. trifluoromethanesulfonyl group is one of the strongest electron-withdrawing ones. Accordingly. we examined the general reducing characteristics of the reagent in order to understand its nature and explore its role in organic synthesis

\section{Results and Discussion}

$\mathrm{Ipc}_{2} \mathrm{BOSO}_{2} \mathrm{CF}_{3}$ was prepared by hydroboration of $\alpha$-pinene with borane-methyl sulfide followed by treatment with trifluoromethanesulfonic acid in $\mathrm{Et}_{2} \mathrm{O}$ (Eq. 1).

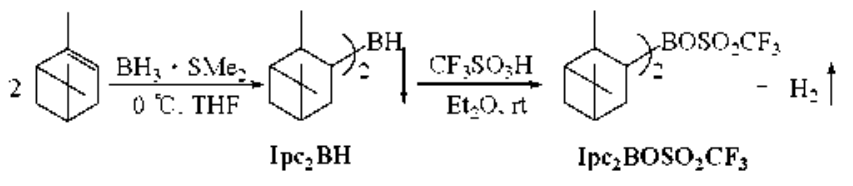

The reactivity of $\mathrm{Ip}_{2} \mathrm{BOSO} \mathrm{CF}_{3}$ toward some representative aldehydes and ketones in $\mathrm{Et}_{2} \mathrm{O}$ was examined. and the results are summarized and compared with those obtained by $\mathrm{Ipc}_{2} \mathrm{BO}_{2} \mathrm{CF}_{3}$ in Table 1 . As shown in the Table. Ipc $\mathrm{BOSO}_{2} \mathrm{CF}_{3}$ readily reduced a variety of aldehydes and ketones examined to the corresponding alcohols at $0{ }^{\circ} \mathrm{C}$. The reactivity of the

"This article is dedicated to the memory of Professor Nung Min Yoon, a pioneer in the field of hydride reduction, who passed away in April 1, 2009. The author keeps in mind his warm-hearted guidance during the graduate school years. reagent toward carbonyl compounds is quite comparable to that of $\mathrm{Ipc}_{2} \mathrm{BO}_{2} \mathrm{CF}_{3}$ reacted in $\mathrm{Et}_{2} \mathrm{O}^{2} \mathrm{As}$ in the reaction of $\mathrm{Ipc}_{2} \mathrm{BO}_{2} \mathrm{CF}_{3}$, the reactivity of $\mathrm{Ipc}_{2} \mathrm{BOSO}_{2} \mathrm{CF}_{3}$ in $\mathrm{Et}_{2} \mathrm{O}$ appeared to be much stronger than that in THF. In general, the reduction of aldehydes by $\mathrm{Ipc}_{2} \mathrm{BOSO}_{2} \mathrm{CF}_{3}$ is nuch faster than that of

Table 1. Reaction of Aldehydes, Ketones and other Functional Compounds with $\boldsymbol{B}$-Trifluorodiisopinocampheylborane ( $\mathrm{Ip}_{2} \mathrm{BOSO}_{2} \mathrm{CF}_{3}$ ) in Ethyl Ether at $0^{\circ} \mathrm{C}^{a}$

\begin{tabular}{|c|c|c|c|}
\hline \multirow{2}{*}{ Compound } & \multirow{2}{*}{$\begin{array}{c}\text { Time } \\
\text { (h) }\end{array}$} & \multicolumn{2}{|c|}{ Yield of alcohol (\%) } \\
\hline & & $\overline{\mathrm{Ipc}_{2} \mathrm{BOSO}_{2} \mathrm{CF}_{3}}$ & $\overline{\mathrm{Ipc}_{2} \mathrm{BO}_{2} \mathrm{CCF}_{3}{ }^{\mathrm{r}}}$ \\
\hline \multirow[t]{2}{*}{ hexanal } & 0.5 & 100 & 99 \\
\hline & 1 & 100 & $99,74^{\circ}$ \\
\hline \multirow[t]{2}{*}{ benzaldehyde } & 0.5 & 99 & 99 \\
\hline & 1 & 99 & 99 \\
\hline \multirow[t]{4}{*}{ o-tolualdehyde } & 0.5 & 100 & 89 \\
\hline & 1 & 100 & 95 \\
\hline & 3 & & 99 \\
\hline & 6 & & 99 \\
\hline \multirow[t]{3}{*}{ p-chlorobenzaldehyde } & 0.5 & 99 & 96 \\
\hline & 1 & 99 & 98 \\
\hline & 3 & & 99 \\
\hline \multirow[t]{2}{*}{ p-methoxylbenzaldehyde } & 0.5 & 100 & 100 \\
\hline & 1 & 100 & 100 \\
\hline \multirow[t]{3}{*}{ 2-naphthaldehyde } & 0.5 & 99 & 98 \\
\hline & 1 & 98 & 99 \\
\hline & 3 & & 99 \\
\hline \multirow[t]{2}{*}{ 2-butanone } & 0.5 & 100 & 100 \\
\hline & 0.5 & 79 & 61 \\
\hline \multirow[t]{3}{*}{ 2-heptanone } & 6 & 99 & 95 \\
\hline & 24 & 99 & 95 \\
\hline & 48 & & 99 \\
\hline \multirow[t]{3}{*}{ acetophenone } & 0.5 & 97 & 97 \\
\hline & 6 & 98 & 97 \\
\hline & 24 & 99 & 98 \\
\hline hexanoyl chloride & 6 & 1 & 0 \\
\hline ethyl caproate & 12 & 0 & 0 \\
\hline benzonitrile & 24 & 0 & 0 \\
\hline
\end{tabular}

"Ten "o excess utilized. "GC yield with a suitable internal standard. " $B$ Trifluorodiisopinocampheylborane. The data cited from ref. 2. "Isolated vield on distillation. 
Table 2. Reaction of $x, \beta$-Unsaturated Aldehydes and Ketoness with $\mathrm{Ip} \mathrm{s}_{\approx} \mathrm{BOSO} \mathrm{CF}_{3}$ in Ethyl Ether at $0{ }^{\circ} \mathrm{C}^{a}$

\begin{tabular}{lcc}
\hline Compound & Time (h) & $\begin{array}{c}\text { Yield of allylic } \\
\text { alcohol }(\%)^{b}\end{array}$ \\
\hline crotonaldelyde & 0.5 & 100 \\
2-hesenal & 0.5 & 98 \\
cinnamaldehyde & 1 & $100,75^{\mathrm{c}}$ \\
isophorone & 0.5 & 99 \\
chalcone & 1 & $100,93^{27}$ \\
& 1 & 85 \\
& 3 & 100 \\
& 3 & 69 \\
& 6 & 97 \\
\hline
\end{tabular}

"Ten ".o excess reagent utilized. "The purity of all allylic alcohol products is absolutely $100^{\circ} \mathrm{iv}$. determined by $\mathrm{GC}$. "Isolated yield on distillation. disolated vield by chromatography.

Table 3. Stereochemistry in the Reduction of Representative Cvclic Ketones with $\mathrm{Ipc}_{2} \mathrm{BOSO}_{2} \mathrm{CF}_{3}$ in Ethyl Ether at $0^{\circ} \mathrm{C}^{\alpha . b}$

\begin{tabular}{llcc}
\hline \multicolumn{1}{c}{ Compound } & $\begin{array}{c}\text { Time } \\
(\mathrm{h})\end{array}$ & $\begin{array}{c}\text { Total vield of } \\
\text { alcohol }(\%)\end{array}$ & $\begin{array}{c}\text { Ratio of more } \\
\text { stable isomer }(\%)^{\circ}\end{array}$ \\
\hline 2-methylcyclohexanone & 0.5 & 98 & $46^{c l}$ \\
3-methylcyclohexanone & 1 & 100 & 46 \\
& 0.5 & 98 & $48^{\circ}$ \\
4-methylcyclohexanone & 1 & 100 & 48 \\
norcamphor & 0.5 & 100 & $49^{q 7}$ \\
camphor & 0.5 & 100 & $88^{\prime}$ \\
& 1 & 71 & $92^{\circ}$ \\
& 24 & 92 & 93 \\
& 72 & 96 & 93 \\
& 120 & 100 & 93
\end{tabular}

"Ten ${ }^{0}$ b excess reagent utilized. ${ }^{b}$ Deternined by GC. "Normalized. ${ }^{\text {"Th }}$ Trus isomer. ${ }^{e}$ Cis isomer. ${ }^{\prime}$ Endo isomer. ${ }^{E} E x o$ isomer.

ketones: most aldehydes are reduced completely within $l \mathrm{~h}$ at $0{ }^{\circ} \mathrm{C}$. whereas ketones require a much longer reaction time under the same reaction conditions. However. $\mathrm{Ipc}_{2} \mathrm{BOSO}_{2} \mathrm{CF}_{3}$ as well as $\mathrm{Ipc}_{2} \mathrm{BO}_{2} \mathrm{CF}_{3}{ }^{2}$ exhibited no reactivity toward acid chlorides. esters and nitriles. making possible the chemoselective reduction of carbonyl compounds in the presence of such inert compounds.

$\mathrm{Ipc}_{2} \mathrm{BOSO}_{2} \mathrm{CF}_{3}$ can also convert $\alpha$ - $\beta$-unsaturated aldehydes and ketones cleanly to the corresponding ally lic alcohols at 0 ${ }^{\circ} \mathrm{C}$. the selectivity being absolutely perfect as summarized in Table 2.

Such a perfect regioselectivity in the reduction of $\alpha . \beta$ unsaturated carbonyl compounds in one of the common and unique features achieved by diisobutỵlalumimum and diisopinocamphey lboron derivatives. ${ }^{3}$ apparently due to the unique reaction mechanism as proposed in the MPV type reactions.

Finally the reagent was applied to the reduction of representative cyclic ketones and its stereochemistry was examined (Table 3 ). The reagent readily reduced all the cyclic ketones examined at $0^{\circ} \mathrm{C}$. However, the stereoselectivity in the reduction appears to be insignificant, showing a quite simple result in sinular to that obtained by $\mathrm{Ipc}_{2} \mathrm{BO}_{2} \mathrm{CF}_{3}{ }^{2}$

In conclusion. $\mathrm{Ipc}_{2} \mathrm{BOSO}_{2} \mathrm{CF}_{3}$ appears to be one of the useful MPV type agents. showing a possibility for chemo- and regioselective reduction. The reagent shows a quite strong reactivity toward aldelydes and ketones. but no reactivity toward most other organic functional groups. In addition, the reagent nicely converts $\alpha \beta$-unsaturated aldehydes and ketones to the corresponding allylic alcohols with a perfect purity. Because of the easy preparation of the reagent using conmercially available chemicals. it should find a role in organic syntheses.

\section{Experimental Section}

All glassware used in this study was predried at $140^{\circ} \mathrm{C}$ for at least 9 hours. assembled hot. and cooled under a stream of dry nitrogen prior to use. All reactions were performed under a dry $\mathrm{N}_{2}$ atmosphere. All chemicals used were commercial products of the highest purity available. which were further purified by standard methods before use. THF and $\mathrm{Et}_{2} \mathrm{O}$ were distilled from sodium-benzophenone ketyl prior to use. Gas chromatographic analy ses were carried out with a varian 3300 chromatograph using a 10\% Carbowax $20 \mathrm{M}$ capillary column $(30 \mathrm{~m})$

Preparation of $B$-Tifluoromethanesulfonyldiisopinocampheylborane ( $\left(\mathbf{L} \mathrm{c}_{2} \mathbf{B O S O _ { 2 }} \mathbf{C F}_{3}\right)$. To an oven-dried. $100-\mathrm{mL}$ flask with a sidearm and a reflux condenser leading to mercury bubbler were added $2.5 \mathrm{~mL}$ of BMS ( $10 \mathrm{M}, 25 \mathrm{mmol})$ and 2 $\mathrm{mL}$ of THF. It was cooled to $0^{\circ} \mathrm{C}$, and $8.5 \mathrm{~mL}(52.5 \mathrm{mmol})$ of $\alpha$-pinene was added dropwise with stirring. After the complete addition of $\alpha$-pinene, the stirring was stoped and the flask was stored at $0^{\circ} \mathrm{C}$ for $6 \mathrm{hrs}$. The supernatant solution was decanted by using a double-ended needle. The crystalline lumps of Ipc2BH was suspended in $\mathrm{Et}_{2} \mathrm{O}(10 \mathrm{~mL})$. and to this was added $5.5 \mathrm{~mL}$ of a $5.0 \mathrm{M}$ solution of trifluorometanesulfonic acid (27.5 nunol) dropwise with stirning. An equivalent of hydrogen gas was evolved immediately. Then the solution was diluted with $\mathrm{Et}=\mathrm{O}$ to be $1.0 \mathrm{M}$.

General Reduction of Carbonyl Compounds with $\mathrm{IpC}_{2}$ $\mathrm{BOSO}_{2} \mathrm{CF}_{3}$. The reaction of hexanal with $\mathrm{Ipc}_{2} \mathrm{BOSO}_{2} \mathrm{CF}_{3}$ is illustrative. An oven-dried, $50 \mathrm{~mL}$ flask. fitted with a sidearm and a bent adapter connected to a mercury bubbler. was charged with $2.5 \mathrm{~mL}$ of a $2.0 \mathrm{M}$ solution of hexanal $(5 \mathrm{mmol})$ in $\mathrm{Et}_{2} \mathrm{O}$ and dodecane as an internal standard. The solution was maintained in a circulating bath at $0^{\circ} \mathrm{C}$. To this was added 5.5 $\mathrm{mL}$ of a stock solution of $\mathrm{Ipc}_{2} \mathrm{BOSO}_{2} \mathrm{CF}_{3}(5.5 \mathrm{mmol})$ in $\mathrm{Et}_{2} \mathrm{O}$ with stirring. At the appropriate time intervals. an aliquot $(c a$. $1 \mathrm{~nL}$ ) was withdrawn, and the mixture was quenched by addition of $\mathrm{NaOH}(3 \mathrm{~N}, 2 \mathrm{~mL})$. The organoborane was then oxidized by addition of $30 \% \mathrm{H}_{2} \mathrm{O}_{2}(1 \mathrm{~mL})$. The aqueous layer was saturated with $\mathrm{K}_{2} \mathrm{CO}_{3}$ and the organic layer was dried over anhydrous $\mathrm{MgSO}_{4}$. The organic layer was then subjected to gas cluromatographic analy sis.

Isolation of Alcohol Products. The following procedure is illustrative for isolation of product alcohols on distillation. In the assembly previously described was placed $30 \mathrm{mmol}$ of carbonyl compound to be reduced in $15 \mathrm{~mL}$ of $\mathrm{Et}_{2} \mathrm{O}$ and the solution was maintained in a circulating bath at $0^{\circ} \mathrm{C}$. Into the silution was injected $33 \mathrm{~mL}$ of a stock solution of $\mathrm{Ipc}_{2} \mathrm{BOSO}_{2} \mathrm{CF}_{3}$ 
(33 mmol) in $\mathrm{Et}_{-} \mathrm{O}$ with stirring, and the reaction mixturewas stirred for the appropriate time of interval. The mixture was then quenched with $3 \mathrm{~N} \mathrm{NaOH}(16 \mathrm{~mL})$ and the organoborane derivative was oxidized by addition of $30 \% \mathrm{H}_{2} \mathrm{O}_{2}(8 \mathrm{~mL})$. The aqueous layer was saturated with $\mathrm{NaCl}$. The separated organic layer was dried over anhydrous $\mathrm{K}_{2} \mathrm{CO}_{3}$. The solvent was evaporated under reduced pressure and a careful fractional distillation gave a desired product. The purity of the product was further confirmed by GC.

The following procedure is representative for isolation of product alcohols by column chromatography. In the assembly was placed $0.61 \mathrm{~g}$ of cinnamaldehy'de $(5 \mathrm{mmol}$ ) in $2 \mathrm{~mL}$ of $\mathrm{Et} \approx \mathrm{O}$ and the flask was maintained in a circulating bath at $0^{\circ} \mathrm{C}$. Into the flask was injected $5.5 \mathrm{~mL}$ of a stock solution of $\mathrm{Ipc}_{2} \mathrm{BOSO}_{2} \mathrm{CF}_{3}(5.5 \mathrm{mmol})$ in $\mathrm{Et}_{2} \mathrm{O}$ with stirring. and the reaction mixture was stirred for $1 \mathrm{~h}$. The mixture was then quenched with $3 \mathrm{NaOH}(2 \mathrm{~mL})$ and the organborane was oxidized by addition of $30 \% \mathrm{H}_{2} \mathrm{O}_{2}(1.5 \mathrm{~nL})$. The solvent was removed under reduced pressure and the impure product was chromatographed on a column of silica gel using a mixture of hexane : ethyl acetate $(10 ; 1)$ as eluent to afford $0.62 \mathrm{~g}(93 \%)$. The purity of product was confirmed by GC.

\section{Refeiences}

1. Cha. J. S.: Nam, H. T.: Jang, S. H.: Kwon, S. Y.: Park, S. I.; Kwon, O. O. Bull. Konew Chem. Soc. 2004, 25, 1948.

2. Cha, J. S.; Nam, H. T.; Park, S. J.; Kwon, S. Y $;$ Kwon, O. O. Ibid. 2006, 27,667.

3. Reviews for MPV reduction, see: (a) Cha, T. S. Org. Process \& Devel. 2006, 10, 1032. (b) Cha, J. S. Bull. Korean Chem. Soc. 2007, 28, 2162 .

4. Cha, J. S.; Yu, S. T.; Roh, M. Y.; Park, S. T.; Yi, J. E.; Kwon, O. O. Bull Korean Chem. Soc. 2008, 29, 885

5. Cohen, R.; Graves, C. R:; Nguyen, S. T:; Martin, T. M. L.; Ratner, M. A. J. Am. Chem. Soc. 2004, 126, 14796 